Research Article

\title{
Actual and Predictive Transport Modeling of Fluoride Contamination of the Sfax-Agareb Coastal Aquifer in the Mediterranean Basin
}

\author{
Samira Melki ${ }^{1},{ }^{1}$ Amina Mabrouk El Asmi, ${ }^{1}$ Mohamadou Ould Baba Sy, ${ }^{2}$ \\ and Moncef Gueddari ${ }^{1}$ \\ ${ }^{1}$ Laboratory of Geochemistry and Environmental Geology, Department of Geology, Faculty of Sciences of Tunis, \\ University of Tunis El Manar, Tunis 2092, Tunisia \\ ${ }^{2}$ Sahara and Sahel Observatory, Tunis 1080, Tunisia
}

Correspondence should be addressed to Samira Melki; melkisamiralefi@hotmail.fr

Received 1 November 2019; Revised 12 March 2020; Accepted 23 March 2020; Published 22 April 2020

Academic Editor: Maurizio Barbieri

Copyright $(2020$ Samira Melki et al. This is an open access article distributed under the Creative Commons Attribution License, which permits unrestricted use, distribution, and reproduction in any medium, provided the original work is properly cited.

The Tunisian coast is suffering from several active or abandoned polluted sites, suspected to have released high concentrations of various contaminants infiltrating the environment and probably causing groundwater degradation. Within this scope, this study comes to assess and model the Sfax-Agareb aquifer contamination by fluoride released through phosphogypsum leachate percolation. For that, a spatial-temporal monitoring of fluoride contents was achieved for the period between October 2013 and October 2014. Observed data show that hazardous water contamination is occurring especially close to the phosphogypsum leachate collection basins. At this level, groundwater fluoride concentrations may reach up to $29 \mathrm{mg} / \mathrm{L}$. Flow and transport modeling to evaluate fluoride contamination plume expansion in 2030 was achieved using MODFLOW and MT3DMS software packages based on a homogeneous and isotropic aquifer conceptual model. Flow and transport model calibrations were assessed by varying hydraulic conductivity, effective porosity, and dispersivity and then validated through observed data for two reference dates (October 2013 and October 2014). Based on the Tunisian NT 106-002 liquid discharge norms, fluoride contamination front was set at $3 \mathrm{mg} / \mathrm{L}$. Numerical simulation shows that, in 2014, plume contamination by fluoride in the saturated zone extended over $250 \mathrm{~m}$ from the contamination source. In 2030, the spatial extent of this contamination will extend over a distance of $900 \mathrm{~m}$ towards the sea, following the aquifer flow direction. At the control piezometer, fluoride concentrations will increase from $29 \mathrm{mg} /$ $\mathrm{L}$ in 2014 to $86 \mathrm{mg} / \mathrm{L}$ in 2030. This study, using numerical modeling, gives new insights for short- and medium-term prediction of eventual fluoride concentrations in the saturated zone of the Sfax-Agareb aquifer.

\section{Introduction}

Industrialization progress during the last century has led to a significant growth of industrial waste, of various toxic products, thrown in the natural environment, hence escalating the risk of its contamination $[1,2]$. Solid byproducts from chemical industries are considered one of the most hazardous forms of pollution that society has created [3]. For that, controlled landfills were installed in developed and underdeveloped countries for its disposal as an alternative solution for this increasing pollution risk. Unfortunately, such resolutions, although delimiting areas of disposals and waste discharges, remain a major source of environmental hazards [4]. More particularly, leachate from certain solid waste disposal sites may contaminate groundwater resources in the immediate vicinity of discharges via diffusive transport, and/or by direct infiltration through landfill coating, and/or by some failure in the leachate collection system [5]. For that, the understanding and comprehension of contaminants nature, their origin, their mode, and their speed of propagation and diffusion are pillar steps in order to implement suitable solutions and to be able to preserve and protect water resources [6]. This most often requires an integrated approach to the problem, including the use of 
properly planned and controlled analytical monitoring as well as mathematical modeling for groundwater contaminant transfer [7].

Contaminant migration, in saturated zones, was previously numerically modeled by Zheng and Wang [8]. The authors implanted a modular three-dimensional multispecies transport model to simulate advection. Later, Mondal and Singh [9] have proposed a solute transport model to evaluate contaminant migration in an industrial belt. Recently, De windt and Spycher [10] have assessed nuclear waste geological disposal through a reactive transport modeling. These simulations allow quantitative and qualitative estimation of contaminant migration as a function of space and time. Added to groundwater flow, contaminant aquifer transfer is also associated with several mechanisms, as, for example, the advection mechanism, hydrodynamic dispersion, adsorption-desorption, and/or degradation [11]. These mechanisms may influence contaminants diffusion, may slow their progression, and may help to degrade them or even their transformation into other substances $[12,13]$. Such schematization via mathematical or numerical modeling allows obtaining key information in order to answer given questions, in particular those concerning the identification of pollution sources, the becoming of pollutants, water resource contamination risks, and the protection and depollution strategy to be implemented [14].

Fluoride-contaminated groundwater has previously been reported in South African countries [15]. The presence of fluorides in groundwater depends on aquifer's geological, chemical, and physical characteristics [16], area tectonic setting, and its related anthropogenic activities [17]. Microfractures due to tectonic setting may even facilitate rapid infiltration of wastewater and leachate into permeable areas and facilitate the circulation of fluids.

The main source of fluoride in groundwater is the dissolution of fluorinated minerals, particularly apatite and fluorine [16]. Fluorides are also released into environment through various industrial activities. Their concentrations may reach more than 100 times the natural content of inorganic fluorides in surface and groundwater [18]. Industries producing and using phosphate fertilizers are among the largest emitters of fluoride [19-22].

In southeastern Tunisia, on the eastern coast of Sfax City, the phosphoric acid $\left(\mathrm{H}_{3} \mathrm{PO}_{4}\right)$ plant produces enormous quantities of phosphogypsum (PG) [23]. The processed crude phosphates originate from the Gafsa area (Southern Tunisia) where sedimentary phosphates are exploited for decades in Tunisia. These phosphates are Lower Eocene in age (Ypresian) and have been thoroughly previously studied from geological, mineralogical, geochemical, structural, and economic point of view $[23,24]$. The used mineral phosphate is the carbonate fluorapatite (CFA) with a common structural formula as follows: $\left(\begin{array}{llll}\mathrm{Ca}_{4,63} & \mathrm{Mg}_{0,13} & \mathrm{Na}_{0,22}\end{array}\right)$ $(\mathrm{PO} 4)_{2,51}(\mathrm{CO} 3)_{0,48}\left(\mathrm{OH}_{0,77} \mathrm{~F}_{0,23}\right)$.

On the other hand, phosphate extraction from the Tunisian Mining Basin of Gafsa-Metlaoui and its associated processing activities in either Gafsa, Gabes, or Sfax have been proved to have an impact on the local landscape and the continental and/or marine ecosystem.
It is worth noting that the presence of fluorides in water resources at contents higher than $1.5 \mathrm{mg} / \mathrm{L}$ [25] generally induces the development of human pathologies such as dental or bone fluorosis. Very large quantities may even have been linked to cancer [26]. In addition, gaseous fluorides and dust have various toxic effects [27]. Furthermore, fluorides can accumulate in plants from phosphate byproducts leaching waters thrown into the environment and contaminating soils. Higher toxicity risks are observed depending on the acidity and alkalinity of the soils [28]. Additionally, plant enzymes exposed to fluorides at a content of around $20 \mathrm{mg} / \mathrm{L}$ are believed to be inhibited. Photosynthetic activity can also be affected as well as plant growth. Leaf necrosis has been observed at concentrations of $\mathrm{F}^{-}$of around $500 \mathrm{mg} / \mathrm{L}$ [27].

In marine ecosystems, as the case of the Gulf of Gabes of Tunisia, aquatic organisms living in estuarine zones are found to be more sensitive to fluorides. A concentration of $0.5 \mathrm{mg} / \mathrm{L}$ can affect aquatic organisms in waters with low ionic strength [27]. Also, fluorides are found to act on the enzymatic activity of fish and on the metabolism of algae. Consequently, the chronic effects of fluorides can lead to the disturbance of metabolism and trophic transfers in fauna and flora in continental and/or marine ecosystems [29].

In the Sfax industrial unit, the carbonate fluorapatite is attacked by sulfuric acid [30]. Therefore, the release of certain impurities such as phosphorus and fluoride after the phosphate attack reaction is not without effect on the surrounding environment, in particular on soil and on water quality [31-33].

Within this context, particular attention is given to the effect of infiltration of acidic leached fluorides on the SfaxAgareb groundwater quality. For that, the present study is a first attempt to model and predict, using the Visual MODFLOW Classic, eventual fluoride concentrations in the saturated zone of the Sfax-Agareb aquifer and the extent of the area affected by the element pollution on short and medium terms. The outcome of this modeling will help to define the adequate means to reduce and eventually remove undesirable effects.

\section{Presentation of the Study Area}

The study area is located on the coastal fringe of Sfax, in southeastern Tunisia, between latitudes $34^{\circ} 43^{\prime}$ and $34^{\circ} 40^{\prime}$ North and longitudes $10^{\circ} 46^{\prime}$ and $10^{\circ} 41^{\prime}$ East (Figure 1). It is located in the industrial zone devoted mainly to phosphate processing, which covers about 120 hectares [34]. The byproduct "PG" is stored on-site, occupying an area of about 50 hectares and reaching a height exceeding $50 \mathrm{~m} \mathrm{[34].}$ Liquid discharge from the phosphoric acid production unit constitutes the most important part of the overall factory waste and it is carried to the PG deposit where it undergoes a decantation that separates the solid phase from gypsum repulping waters [35]. Phosphogypsum deposit leaching, under the effect of rainwater, causes the transfer of pollutants to surrounding aquatic environments and to neighboring groundwater [36]. The leachates are collected in 


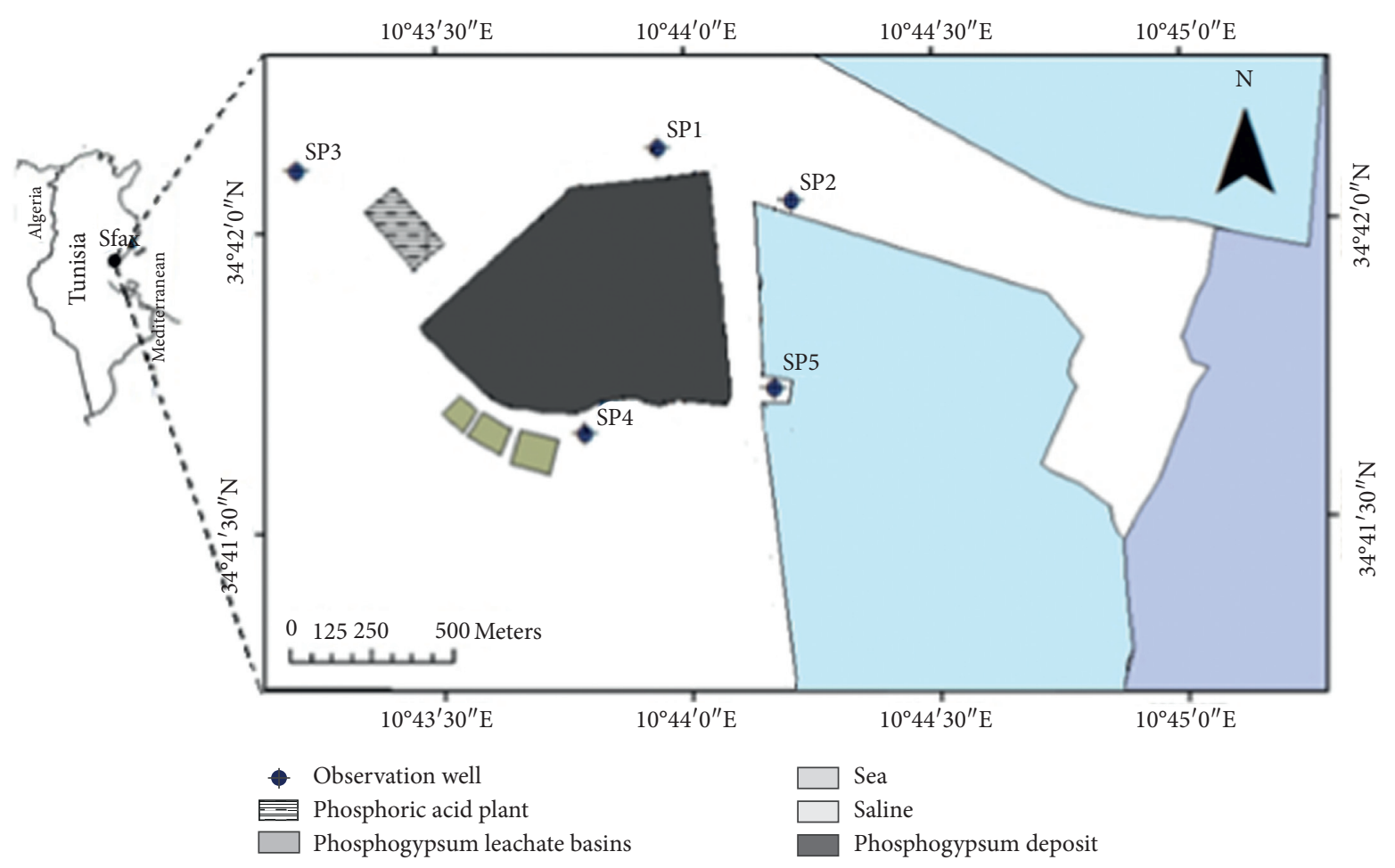

Figure 1: Location map of the study area and observation well sampled for groundwater analysis.

basins, southwest of the phosphogypsum deposit, before being rejected into the sea (Figure 1).

The low-altitude study area is under the influence of a dry and hot Saharan climate of southwest of Tunisia and the relatively humid and temperate Mediterranean climate characterizing eastern and northern Tunisia. The average annual rainfall for the period between 2005 and 2015 is about $220 \mathrm{~mm} /$ year [37]. The average monthly rainfall varies between $47 \mathrm{~mm}$ in October, considered as the wettest month, and $1.2 \mathrm{~mm}$ in July, corresponding to the driest month [30]. The average annual evaporation is $1883 \mathrm{~mm}$ for the period between 2005 and 2015 [30] and the average monthly evaporation ranges from a $112 \mathrm{~mm}$ low in January to $243.5 \mathrm{~mm}$ high in July [37].

\section{Geological and Hydrogeological Features of the Study Area}

The outcropping geological formation of the study area (Figure 2(a)) consists mainly of sandy clays rich in gypsum and silty sands [39] of Miocene-Pliocene to Early Quaternary age [40]. The phosphate processing industry is built on relatively recent alluvium consisting mainly of sands, alluvia, and calcareous gypsatic crusts. The study area (Figure 2(b)) is part of the Sfax-Agareb phreatic aquifer which is constituted of Miocene-Pliocene-Quaternary sand-clay sediments of the Segui Formation [38, 41]. Underneath the phosphogypsum deposits, the sandy formation aquifer was encountered from 4 to $7 \mathrm{~m}$ [42]. The horizontal permeability of the aquifer was measured in situ by the Lefranc tests in the vicinity of boreholes. It ranges from $8 \times 10^{-6}$ to $1 \times 10^{-3} \mathrm{~m} / \mathrm{s}$ [42]. The piezometric map, elaborated based on measurements made in five piezometers (Figure 3) during October
2013, shows water table levels fluctuating between 1.5 and $5 \mathrm{~m}$ depth and flowing according to a west-east direction. Water supply is provided mainly by meteoric water infiltrations. The recharge rate is estimated around $7.6 \mathrm{~mm} /$ year [43]. The hydraulic gradient of the Sfax-Agareb aquifer, captured by the five piezometers, increases upstream to downstream and ranges from 0.001 to 0.004 , with an average of 0.002. Piezometric level monitoring, conducted between October 2013 and October 2014 (Figure 4), indicates an almost steady state with the exception of piezometer SP1 where a small increase was recorded in March 2014.

\section{Materials, Methods, and Modeling Tools}

4.1. Sampling and Geochemical Analyses. Groundwater sampling was conducted on a bimonthly basis in order to acquire representative data for fluoride content spatial and temporal distribution and to define the contamination source. Using a submerged pump, samples were collected during six campaigns between October 2013 and October 2014 from five piezometers implanted in the phosphate plant and complying with sampling standards. The $\mathrm{pH}$ and electrical conductivity (EC) were checked all through and measured in situ using calibrated portable digital meters [44]. The analysis of phosphogypsum (PG) leachates was carried out in October 2013 and in October 2014 from the collection basins, southwest of the phosphogypsum deposit. Water samples were stabilized by adding few drops of diluted $\mathrm{HNO}_{3}$ and filtered to remove the suspended matter. They were subsequently analyzed by ionic liquid chromatography ISO 10304-1. The aqueous sample is injected into an anionic column to separate the desired ions according to 


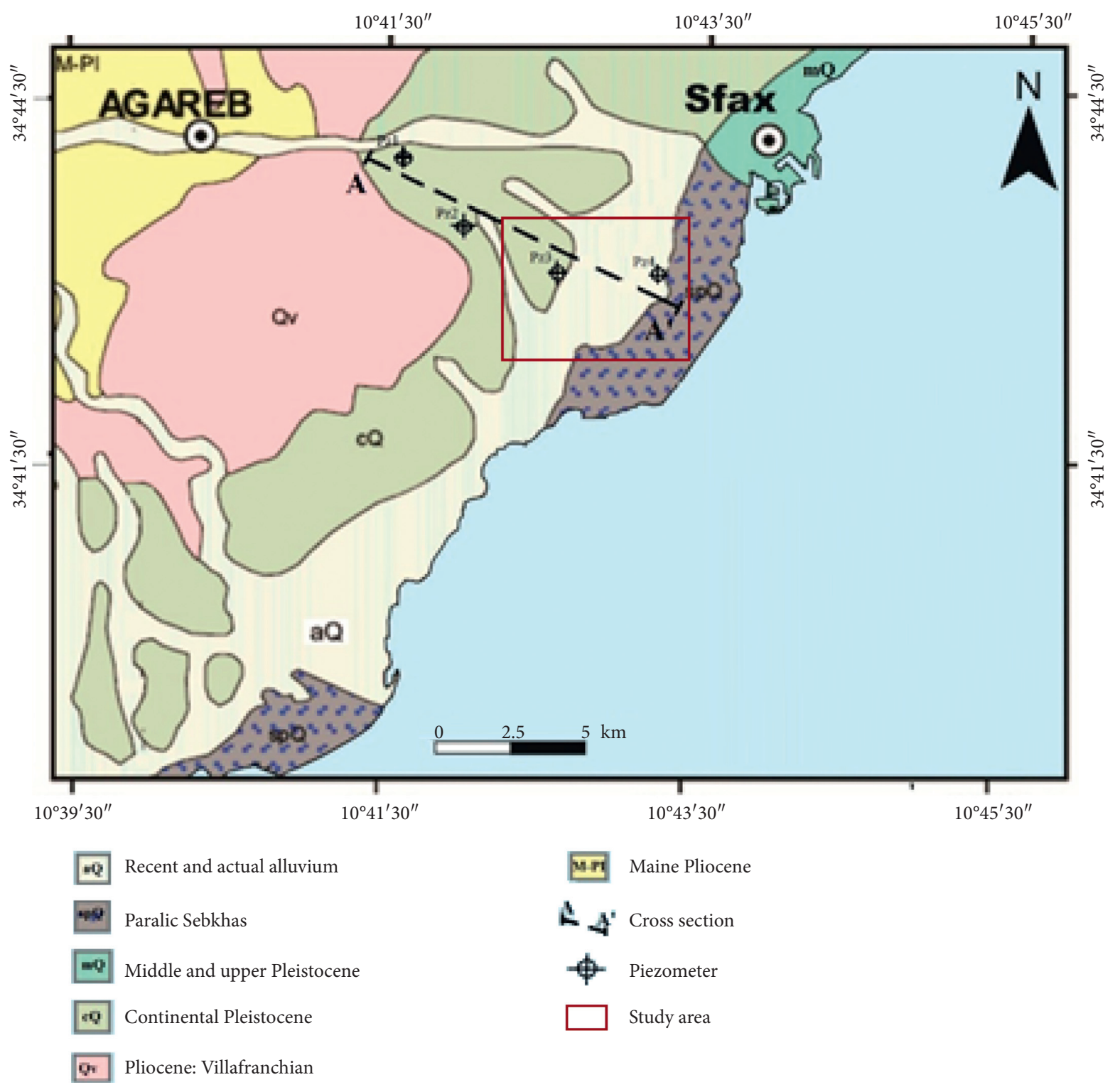

(a)

Figure 2: Continued. 


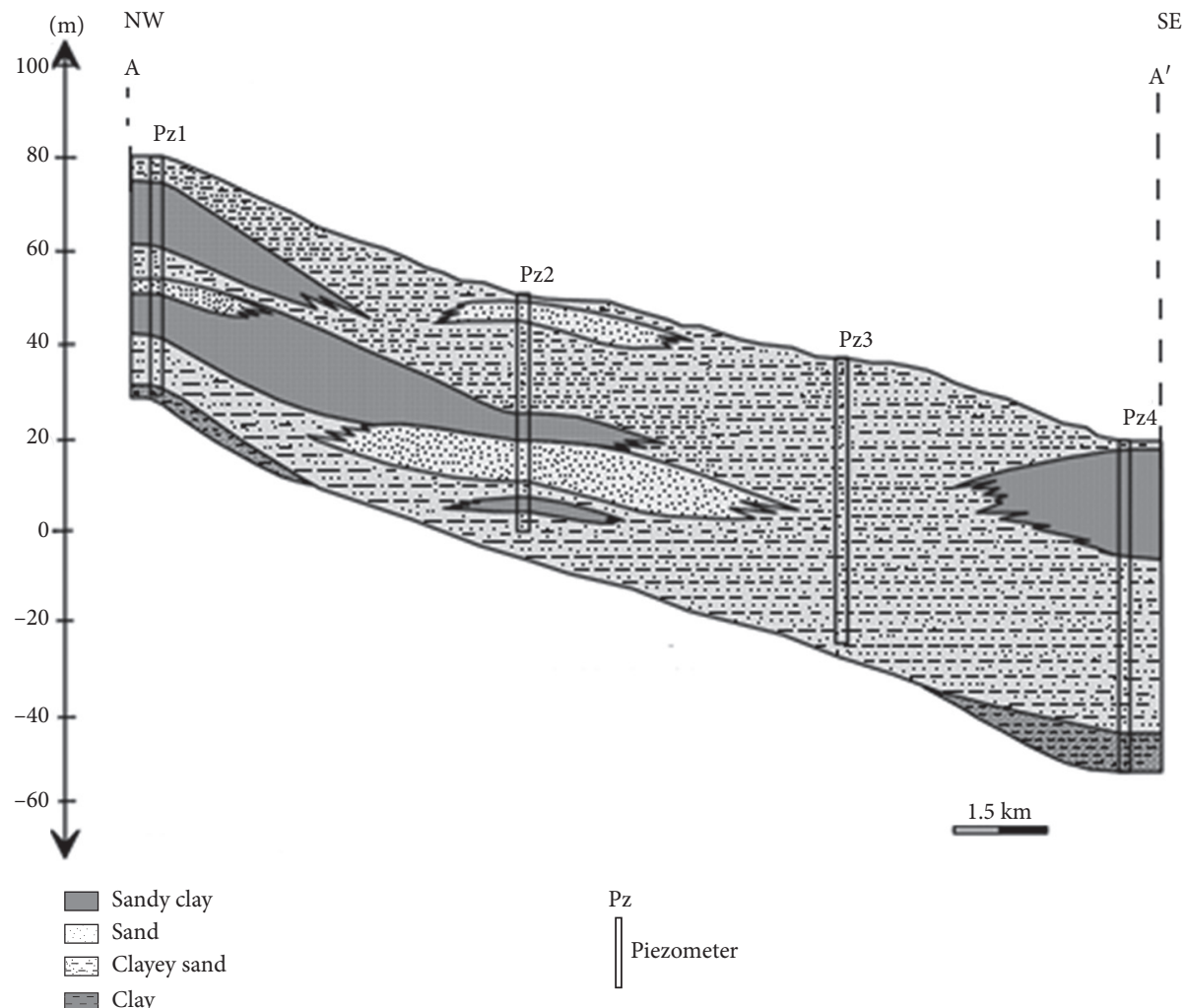

(b)

FIGURE 2: Geological map of Sfax-Agareb region (a) and hydrogeological cross section along transect $\mathrm{AA}^{\prime}$ (b) [38].

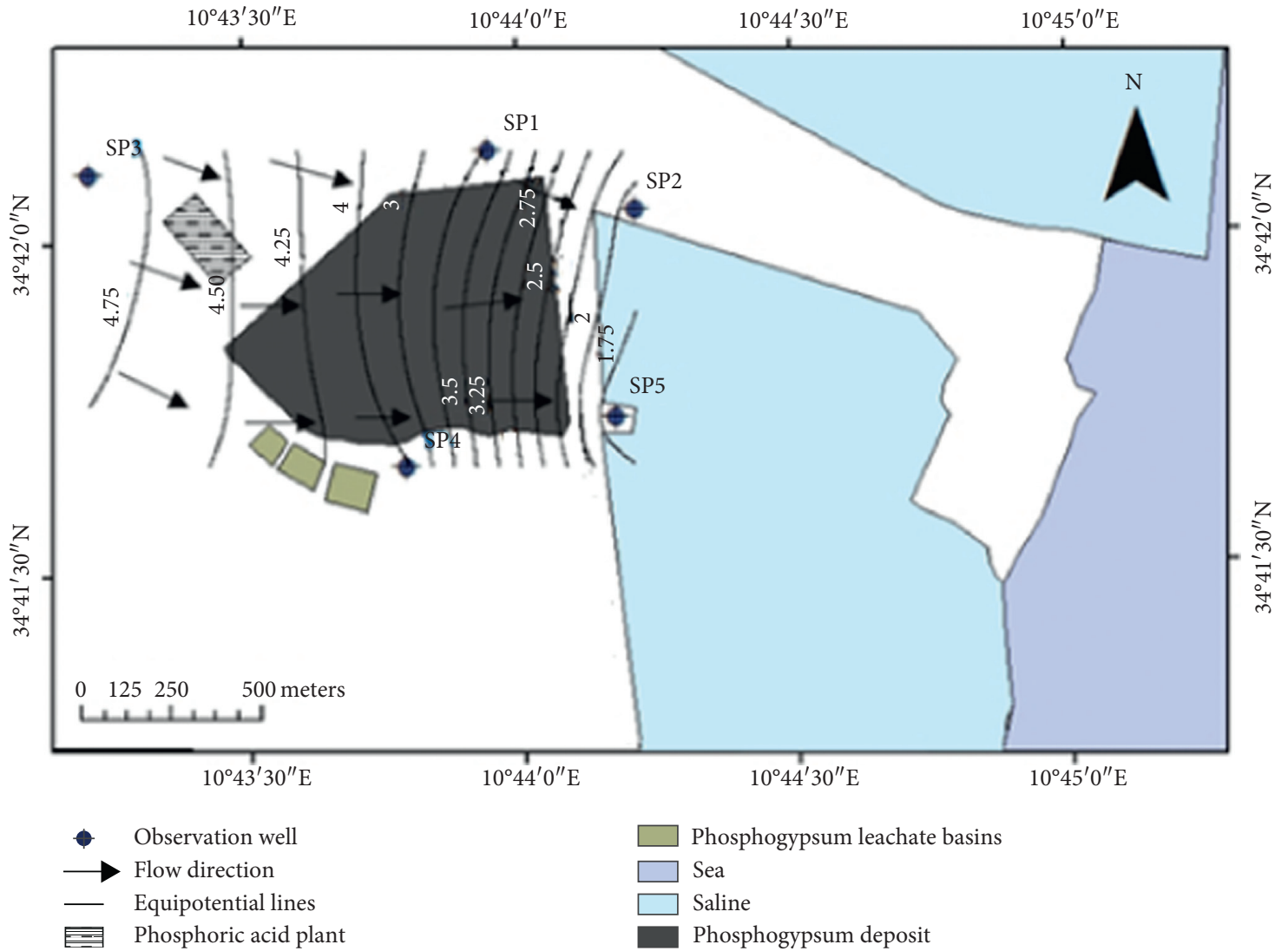

FIgURe 3: Piezometric map of Sfax-Agareb phreatic aquifer at the PG deposit during October 2013. 


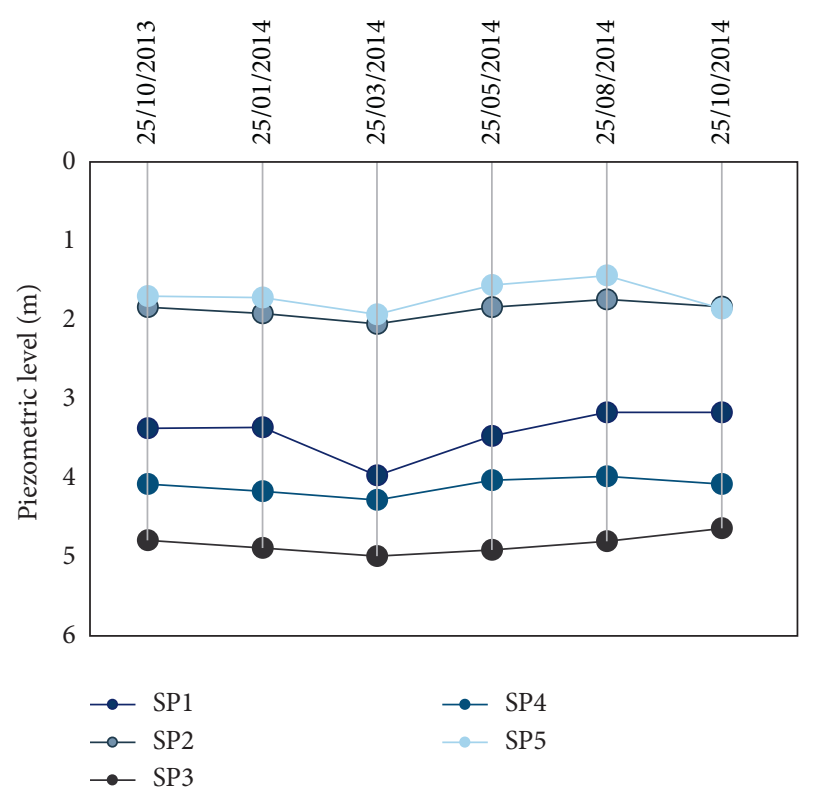

FIGURE 4: Piezometric level spatiotemporal monitoring during 20132014 in the Sfax-Agareb phreatic aquifer around the PG deposit.

their charges and sizes. The fluoride ions are separated and quantified by means of a conductometric detector positioned at the column outlet. The relative uncertainty including the measurement accuracy of the repeatability error is less than 3\%. Gathered results are presented in Table 1.

4.2. Choice of Model and Used Flow and Transport Equations. The choice of an adapted model to a given case depends on a certain number of elements, particularly the characteristics of the aquifer system, the objectives pursued, and the expected accuracy [45]. For that, the MT3DMS code, developed by Papadopoulos and associates [40] incorporated in the MODFLOW, Classic version 4.2, developed by the United States Geological Survey USGS [46] and Waterloo Hydrogeologic Software, is used to simulate solute transport in a three-dimensional saturated zone [46]. The MODFLOW allows calculation of water flows and piezometric heights from Darcy's law and diffusivity equation. These flows are then used by MT3DMS to simulate the transport of pollutant in the aquifer [47]. The coupling between both codes assumes that the concentrations of the solutes do not affect the hydrodynamic properties of the fluid [48]. Water transfers and miscible pollutants in saturated porous media are described by the following equations [49]:

Darcy's law:

$$
\begin{aligned}
& V x=-K x x \frac{\partial h}{\partial x}, \\
& V y=-K y y \frac{\partial h}{\partial y}, \\
& V z=-K z z \frac{\partial h}{\partial z},
\end{aligned}
$$

where $V x, V y$, and $V z$ are the $x, y$, and $z$ components of the Darcy velocity, $K x, k y$, and $k z$ are coefficient of permeability along the three main orthogonal directions, and $h$ is the hydraulic gradient.

The flow equation (or diffusivity):

$$
\begin{aligned}
& \frac{\partial}{\partial x}\left(K x x \frac{\partial h}{\partial x}\right)+\frac{\partial}{\partial Y}\left(K y y \frac{\partial h}{\partial y}\right)+\frac{\partial}{\partial z}\left(K z z \frac{\partial h}{\partial z}\right)-S \frac{\partial h}{\partial t} \\
& \quad+\sum_{i=1}^{r} W_{i} \delta(x-x i) \delta(y-y i) \delta(z-z i)=0,
\end{aligned}
$$

where $S$ is specific storage, $r$ is the source number (wells), and $W_{i}$ is the volumetric flux rate per unit volume.

The dispersion (or transport) equation [46]:

$$
\begin{aligned}
& \frac{\partial}{\partial x}\left[D x x \frac{\partial C}{\partial x}+D x y \frac{\partial C}{\partial y}+D x z \frac{\partial C}{\partial z}\right] \\
& +\frac{\partial}{\partial y}\left[D y x \frac{\partial C}{\partial x}+D y y \frac{\partial C}{\partial y}+D y z \frac{\partial C}{\partial z}\right] \\
& +\frac{\partial}{\partial z}\left[D z x \frac{\partial C}{\partial x}+D z y \frac{\partial C}{\partial y}+D z z \frac{\partial C}{\partial z}\right] \\
& \quad-\left[V x \frac{\partial c}{\partial x}+V y \frac{\partial c}{\partial y}+V z \frac{\partial c}{\partial z}\right] \\
& \quad+Q\left(C^{w}-C\right)-n_{e}[1+E(C)]\left(\frac{\partial C}{\partial t}\right)=0,
\end{aligned}
$$

where $C$ is the pollutant concentration. $E(C)$ is a function representing the chemical adsorption properties, $C^{w}$ is the concentration of the pumped fluid, and Dxx, Dyy, Dzz, Dyx, $D y z$, and $D z x$ are components of the hydrodynamic dispersion tensor [46].

\section{Results and Discussion}

5.1. Fluoride Contamination Assessment. At the catchment basins, southwest of the PG deposit, the analyzed leachates are found heavily charged with fluoride displaying $1905 \mathrm{mg} /$ $\mathrm{L}$ in October 2013 and $2100 \mathrm{mg} / \mathrm{L}$ in October 2014. Such contents exceed the national norm of $3 \mathrm{mg} / \mathrm{L}$ set for fluoride in effluents representing treated or not treated wastewater discharge, directly or indirectly thrown into the receiving environment [50]. The leachates display very low $\mathrm{pH}$ (1.3) and show the highest EC values (Table 1).

Analyzed groundwater conductivities vary between 8810 and $34900 \mu \mathrm{s} / \mathrm{cm}$, being the lowest in the upstream part of the study area and the highest in the southeastern part of the aquifer at piezometer SP4 (Figure 5(a)). A significant increase is observed, following the groundwater flow direction (west-east), related to water-sediment interaction of the 
TABLE 1: Chemical composition of groundwater samples and PG leachates.

\begin{tabular}{lcccccccccccccccccc}
\hline Date & \multicolumn{3}{c}{ Oct 2013 } & \multicolumn{4}{c}{ Jan 2014 } & \multicolumn{4}{c}{ Mar 2014 } & \multicolumn{4}{c}{ May 2014 } & \multicolumn{4}{c}{ Aug 2014 } & \multicolumn{3}{c}{ Oct 2014 } \\
Parameters & $\mathrm{pH}$ & $\mathrm{EC}$ & $\mathrm{F}^{-}$ & $\mathrm{pH}$ & $\mathrm{EC}$ & $\mathrm{F}^{-}$ & $\mathrm{pH}$ & $\mathrm{EC}$ & $\mathrm{F}^{-}$ & $\mathrm{pH}$ & $\mathrm{EC}$ & $\mathrm{F}^{-}$ & $\mathrm{pH}$ & $\mathrm{EC}$ & $\mathrm{F}^{-}$ & $\mathrm{pH}$ & $\mathrm{EC}$ & $\mathrm{F}^{-}$ \\
\hline SP1 & 5.18 & 16050 & 1.3 & 5.75 & 15990 & 2 & 5.58 & 16330 & 0.6 & 5.56 & 15710 & 0.5 & 5.2 & 15820 & 1.2 & 5.5 & 15100 & 0.7 \\
SP2 & 6.35 & 15300 & 6 & 6.64 & 15010 & 6 & 6.7 & 15270 & 4.5 & 6.68 & 14860 & 3.3 & 6.03 & 14870 & 4 & 6.6 & 14630 & 3.7 \\
SP3 & 6.88 & 8900 & 8 & 7.03 & 8810 & 6 & 7.17 & 8950 & 4.6 & 7.1 & 8900 & 3.5 & 6.74 & 8900 & 7.6 & 6.9 & 9220 & 3.3 \\
SP4 & 6.17 & 33000 & 17 & 6.71 & 34100 & 27 & 6.78 & 34600 & 19 & 6.76 & 34300 & 19 & 6.36 & 34700 & 17 & 6.26 & 34900 & 29 \\
SP5 & 6.25 & 15790 & 4 & 6.58 & 16200 & 5 & 6.63 & 16310 & 3.2 & 6.58 & 16040 & 2.6 & 6.25 & 16420 & 3.9 & 6.6 & 17250 & 2.4 \\
PG leachate & 1.3 & 22350 & 1905 & & & & & & & & & & & & & 2.2 & 22700 & 2100 \\
\hline
\end{tabular}

Electrical conductivity: EC $(\mu \mathrm{S} / \mathrm{cm})$; fluoride: $\mathrm{F}^{-}(\mathrm{mg} / \mathrm{L})$.

unsaturated zone, and/or salty water intrusion, and/or PG leachate infiltration [35].

The analyzed water $\mathrm{pH}$ is acid to near neutral, with values ranging from 5.18 to 7.6 . The lowest $\mathrm{pH}$ concerns the downstream part at piezometer SP1, which is under the direct influence of PG leachate infiltrations, while the highest $\mathrm{pH}$ characterizes the upstream part (SP3). A slight increase in $\mathrm{pH}$ is recorded during the water table recharge period (January and March) due to a mixing effect caused by infiltrated rainwater (Figure 5(b)).

At the industrial zone, the fluoride Sfax-Agareb groundwater contents vary between 0.5 and $29 \mathrm{mg} / \mathrm{L}$ throughout both sampling periods. The highest contents are measured in waters sampled from piezometers located around the PG leachate collection basins, in particular piezometer SP4 (Figure 5(c)). Moreover, for the same piezometer, the fluoride content variation, over time, is known to decrease during the recharge period of the aquifer compared to the rest of the year.

5.2. Conceptual Model Construction. The choice of the conceptual model is conditioned not only to seek a high degree of precision, but also by the quantity and quality of the available data [51].

The construction of the groundwater flow and transport conceptual model was based on field data, hydrogeological and geotechnical interpretation outcomes, and bimonthly fluoride measurement results for the year 2013-2014. The following assumptions were made during the construction of the flow and transport model in the saturated zone of the Sfax-Agareb aquifer:

(i) Flow modeling in a steady state

(ii) Flow occurring towards the sea, deduced from the interpretation of the piezometric maps carried out for the year 2013-2014

(iii) The migration of contamination is horizontal, according to groundwater flow direction

(iv) The selected contaminant is fluoride $\left(\mathrm{F}^{-}\right)$because of its high content recorded throughout the monitoring period

(v) Only contaminant dispersion is considered, the adsorption being assumed to be negligible

(vi) The initial concentration of the pollutant element introduced into the model outside the "source zones" is $0 \mathrm{mg} / \mathrm{L}$ (vii) The fluoride levels in the "source zone" of contamination are based on those measured in phosphogypsum leachates in October 2013 and October 2014

5.3. Flow Conceptual Model. Based on the geotechnical characterization report of Sfax [42], the following lithological succession is recognized from top to bottom:

(i) 1 to $2 \mathrm{~m}$ thick filling layer with a hydraulic conductivity $(K)$ varying from $1.10^{-7}$ to $1.10^{-6} \mathrm{~m} / \mathrm{s}$

(ii) 2 to $3 \mathrm{~m}$ of sandy clays and phosphogypsum mix $\left(K=1 \times 10^{-8} \mathrm{~m} / \mathrm{s}\right)$

(iii) 10 to $14 \mathrm{~m}$ of slightly gravelly sand layer, relatively permeable with a hydraulic conductivity ranging from $8 \times 10^{-6}$ to $1 \times 10^{-3} \mathrm{~m} / \mathrm{s}$

(iv) Very low permeability limy clays $\left(K=1 \times 10^{-9} \mathrm{~m} / \mathrm{s}\right)$.

The aquifer is considered unconfined and corresponds to a single layer of fine sand, 10 to $14 \mathrm{~m}$ in thickness, and displaying a hydraulic conductivity ranging between $8 \times 10^{-6}$ and $1 \times 10^{-3} \mathrm{~m} / \mathrm{s}$ based on the Lefranc tests. The model is therefore a monolayer free aquifer set on a very low permeability clay substratum (Figure 6).

5.4. Transport Conceptual Model. A solute transport model was developed to study the long-term spatial and temporal evolution of fluoride contents, from October 2014 to October 2030. Changes in short-term concentrations between October 2013 and October 2014, associated with small fluctuations in piezometric levels and lack of pumping in the area, must therefore be replicated [52]. The flow model can therefore be assumed permanent and modeled under stationary conditions, using average conditions for this period.

Based on the bimonthly monitoring of Sfax-Agareb groundwater quality for the period between October 2013 and October 2014, abnormal high concentrations of $\mathrm{F}^{-}$, reaching $29 \mathrm{mg} / \mathrm{L}$ at piezometer SP4, were recorded. These high contents would have a fluoride contamination source located southwest of the phosphogypsum deposit, upstream of hydraulic piezometer SP4 where the PG leachate collection basins are placed.

5.5. Grid, Boundary Conditions, and Calibration of the Flow Model. The study area was discretized into "cells" of $50 \mathrm{~m}$ sided (Figure 7). Geometrical and hydrodynamic parameters 

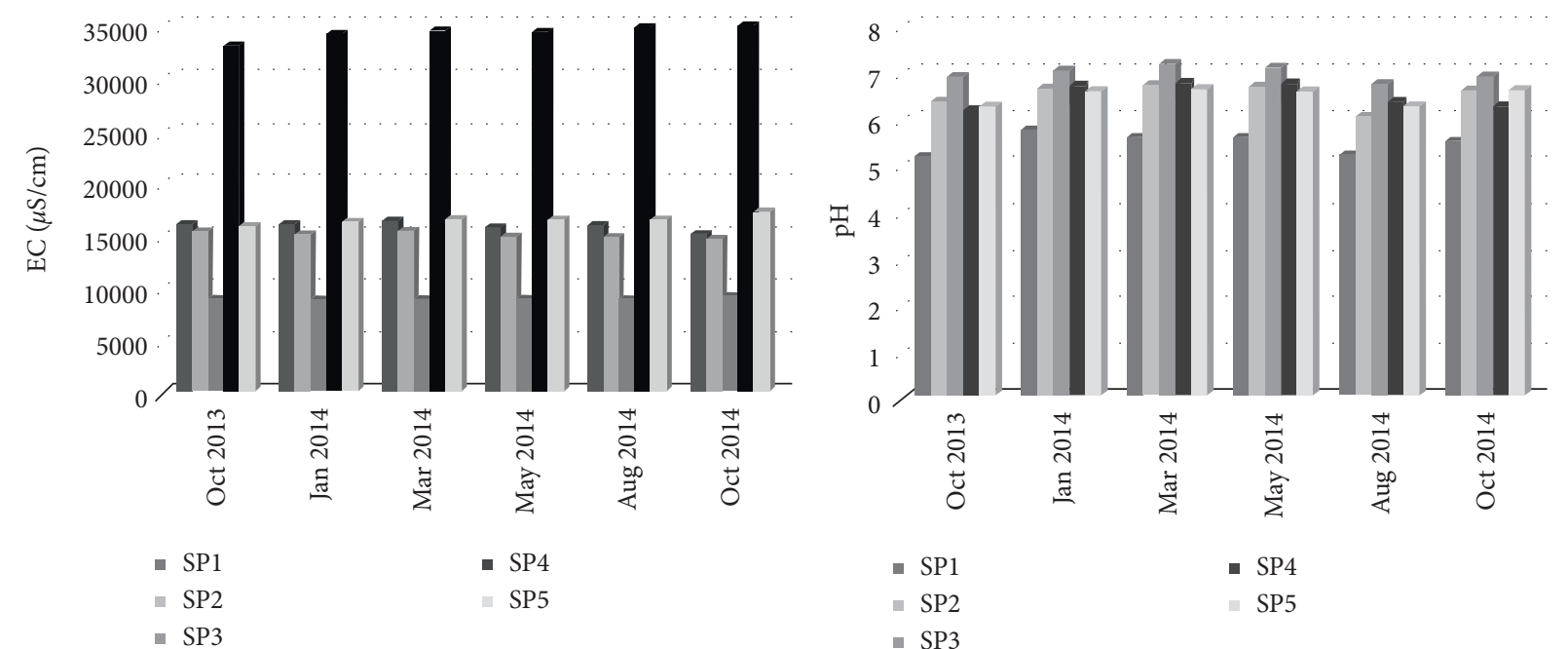

(a)

(b)

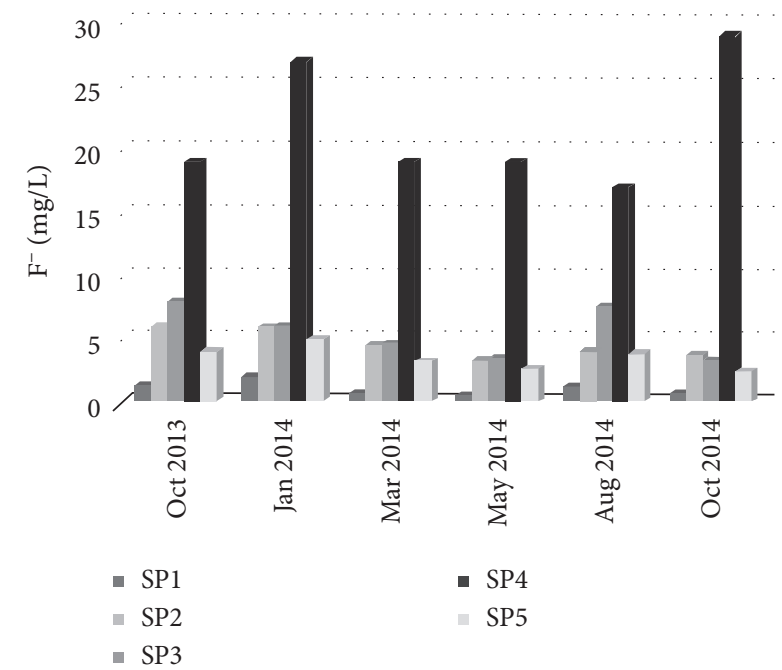

(c)

Figure 5: Distribution of EC (a), pH (b), and fluoride concentration (c) in Sfax-Agareb groundwater around the PG deposit.

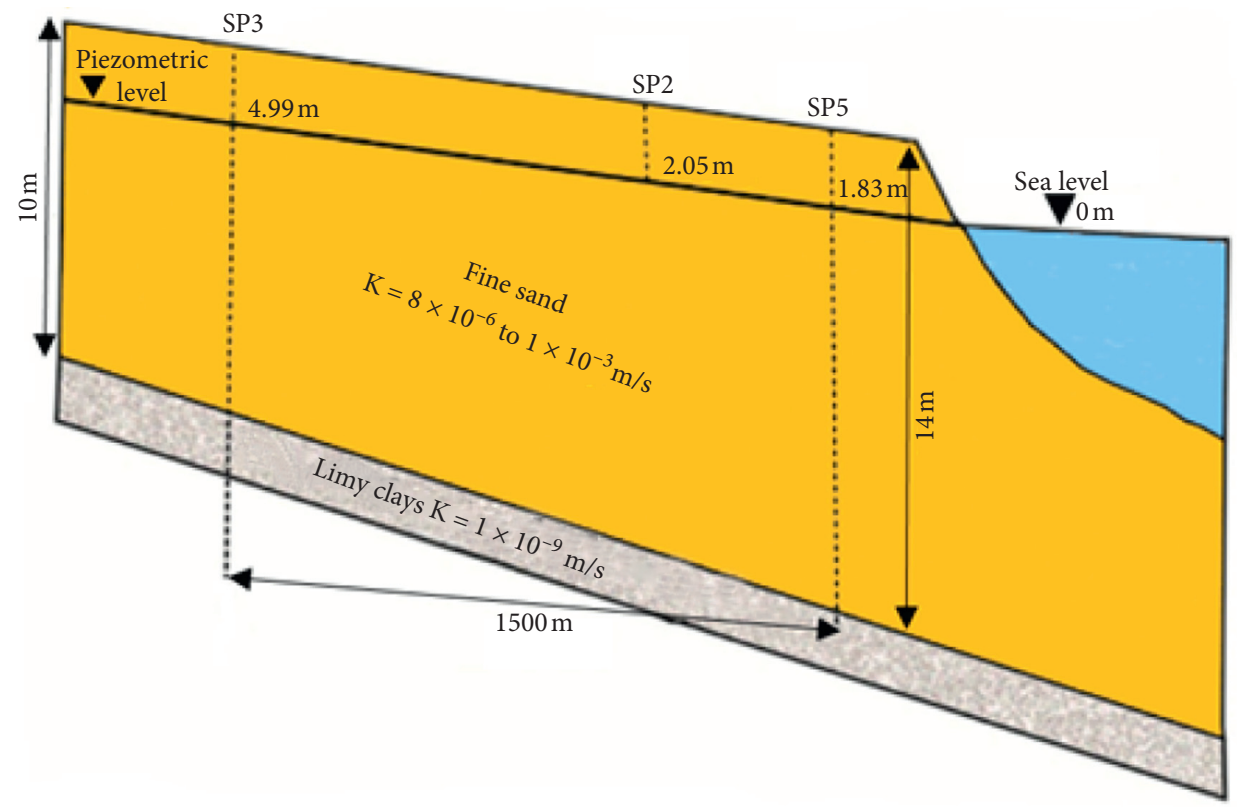

Figure 6: Conceptual model of Sfax-Agareb phreatic aquifer at the PG deposit. 
necessary for the simulation are attributed to each cell. Boundary conditions can be defined as either (i) conditions with imposed potentials, (ii) conditions with imposed flow, or (iii) conditions with imposed drain [53,54].

In a constant regime, we impose potential values as boundary conditions. The translation of these conditions into the MODFLOW code is represented by a table (IBOUND) which allows to ensure if a particular cell is active, inactive, or with a fixed load. When a natural limit, such as the sea or a river, does not exist, a potential line resulting from measurements at the edges of the model domain can be used as a condition of imposed potential. Two boundary conditions of constant head type were applied at the flow model fringes, the first representing the sea and the second corresponding to the upstream side of the industrial site. The sea level is taken at elevation $0 \mathrm{~m}$ and the upstream hydraulic load at $5 \mathrm{~m}$, calculated via the hydraulic gradient. The bottom is defined as an impermeable boundary because the exchange between the sand aquifer and the clay substratum is minimal and can be ignored. In the case of an unconfined aquifer, an important boundary condition is imposed on the surface of the model. This condition is represented by meteoric water recharge.

In the Sfax industrial zone, the calibration was carried out trying to reproduce as closely as possible the behaviour of the real hydrogeological system and obtain similar piezometric levels as measured in October 2013. This was achieved by varying horizontal hydraulic conductivity values of sand. We then compared the simulated piezometric levels to those measured at a given moment.

For this calibration step, the normalized RMS represents the average normalized square errors. This is the standard deviation that exists between these two sets of data. This calibration step is very important to minimize the normalized RMS to the lowest possible value [55]. The normalized RMS is at $39.27 \%$ before calibration, which indicates the large difference between the calculated hydraulic heads and those measured in 2013. After numerous calibrations by varying the horizontal hydraulic conductivity of sand, the normalized RMS value was reduced to $10.13 \%$ (Figure 8).

The established calibration shows a good consistency between the simulated flow and the natural flow of the aquifer since the majority of control points introduced into the flow model are within the $95 \%$ confidence interval (Figure 8).

Furthermore, the examination of the calculated piezometric map confirms the west-east flow direction (Figure 9). Flow parameters and calibrated values are shown in Table 2.

5.6. Numerical Fluoride Transport Model Calibration. Once calibrated, the flow model can be used to calibrate the transport model. A migration or transport model is composed of a "source zone" (Figure 7) and a "plume" of contamination that migrates along the direction of the aquifer flow in relation to the source zone.

To locate the plume, average concentrations of contaminant in each piezometer waters were considered for the six sampling campaigns. The contaminated zone was delimited in relation to concentration gradients between the upstream side, at piezometer SP3, and the downstream side. Results, herein reported, were compared to the Tunisian norms related to liquid discharges (NT 106-002). Subsequently, each panache was linked to a potential source of contamination.

Refinement of cells near the source zone and the control piezometers (Figure 7) as well as the sand dispersivity have been first adjusted in order to obtain the previously observed concentration (October 2014). The dispersivity values used for the transport model fit were selected from the literature for a medium of a similar nature.

Using available location and source history data, calculations of contaminant migration velocity and hydraulic conductivity applicable to saturated permeable horizons were performed as follows:

$$
K=V \frac{n e}{i},
$$

where $K$ is the hydraulic conductivity, $i$ is the hydraulic gradient, $n e$ is the effective porosity, and $V$ is the migration speed, which is given by

$$
V=\frac{S}{t},
$$

where $S$ is the migration distance, i.e., the distance between the source and the contaminated piezometer, and $t$ is simulation time.

From (5) and (6), we obtain the calculated hydraulic conductivity:

$$
K=\frac{S}{t} \frac{n e}{i} .
$$

During the transport model calibration, the hydraulic conductivity was adjusted to allow migration between the source and the control piezometer. Fluoride contamination was introduced into the model, assuming a constant and continuous source of contamination located to the southwest of the phosphogypsum deposit. In this case, the boundary condition is of constant concentration type.

The fluoride-related source of contamination was activated in the model during the period between October 2013 and October 2014 (365 days). The forecast simulation of contamination was of 6205 days (16 years). The transport model calibration aimed to adjust the $\mathrm{F}^{-}$concentrations to approach $\mathrm{F}^{-}$contents measured in 2014, at the control piezometer (SP4).

The calibration results indicate a very good agreement between the fluoride measured concentrations and those simulated. A low deviation between measured and simulated values of the order of $0.14 \mathrm{mg} / \mathrm{L}$ is recorded at the control piezometer SP4 (Figure 10).

The preliminary transport parameters and the calibrated values are shown in Table 3.

5.7. Forecast Simulations. Numerical simulation has allowed to delineate the aquifer fluoride contamination expansion and to highlight the most polluted sites. The simplified scenario considered for this study consisted of a linear 


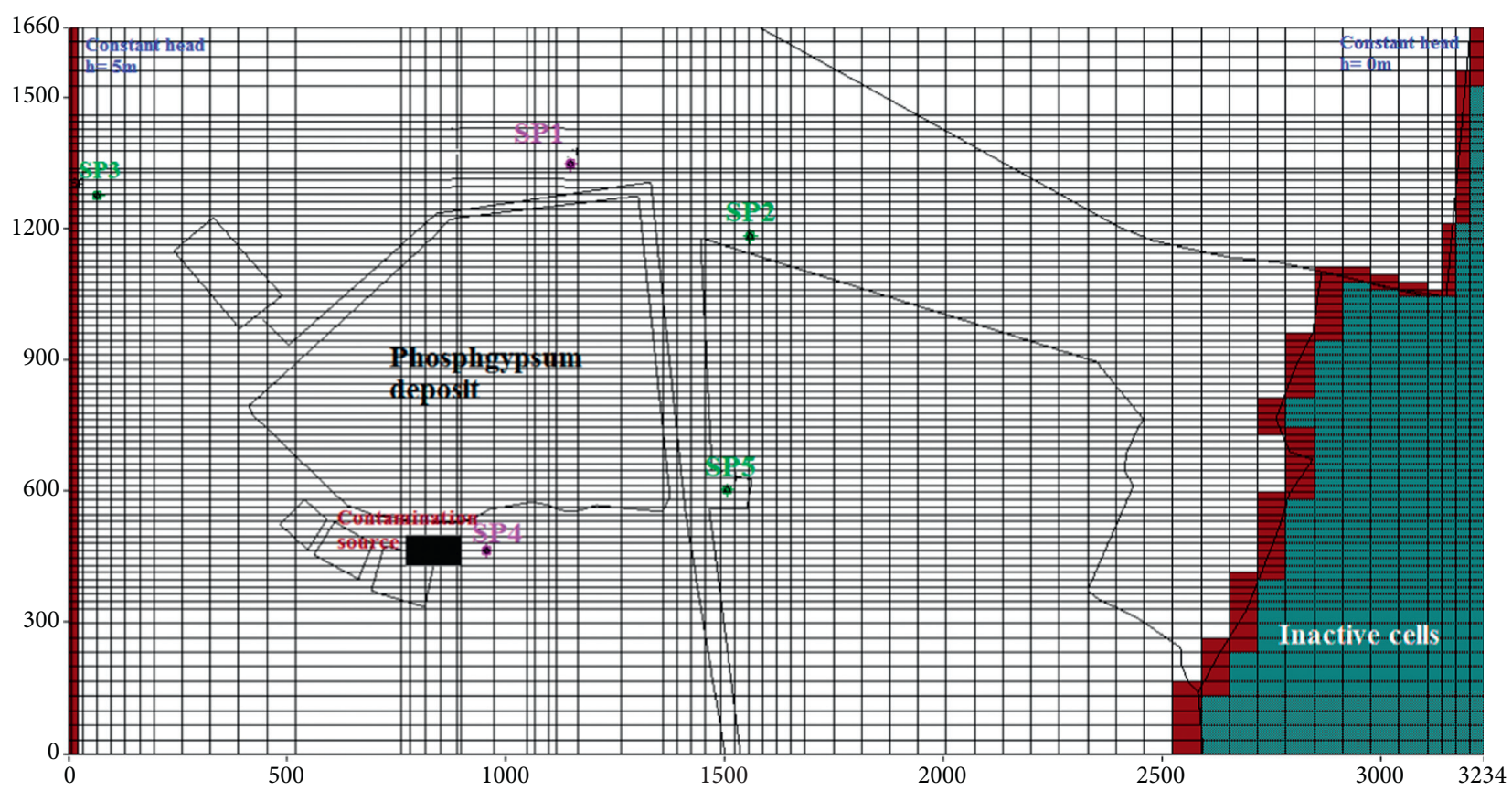

Figure 7: Model domain grid and the boundary conditions of the simulated Sfax-Agareb phreatic aquifer at the PG deposit.

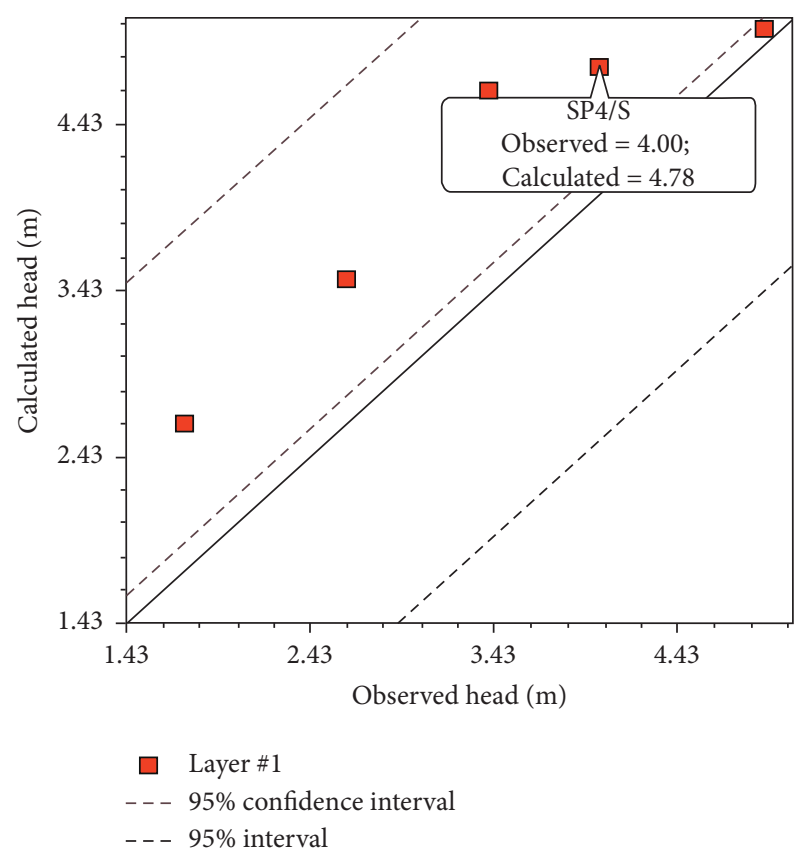

FIGURE 8: Calculated and observed head for the steady-state condition after calibration.

increase of fluoride from $17 \mathrm{mg} / \mathrm{L}$ in 2013 to $29 \mathrm{mg} / \mathrm{L}$ in 2014 and a prediction for the year 2030 .

In the saturated zone of the Sfax-Agareb aquifer, at the phosphogypsum storage site and according to the two time references (October 2013 and October 2014), predictive simulations were established to evaluate fluoride contamination plume extension up to 2030. Based on the Tunisian norms of liquid discharges (NT 106-002), the fluoride contamination fronts were set at $3 \mathrm{mg} / \mathrm{l}$.
The water quality of the Sfax-Agareb aquifer, near the phosphogypsum discharge, is deteriorating significantly and continuously. The model foresees extensions of the contaminated plume over $250 \mathrm{~m}$ in 2014 (Figure 11(a)) away from the source area. It forecasts an extension over $900 \mathrm{~m}$ in 2030 (Figure 11(b)). The contamination plume will bear an ellipsoid shape. The variation of concentrations calculated as a function of time (Figure 10) predicts fluoride content increase from $29 \mathrm{mg} / \mathrm{L}$ in 2014 to $86 \mathrm{mg} / \mathrm{L}$ in 2030 . However, and taking into consideration the various assumptions mentioned in previous sections, we consider that this expansion is a worst scenario as retardation may occur with time and through sorption and through element complexation. These processes were not considered in the modeling.

\section{Conclusion}

In the current study, a bimonthly spatial-temporal monitoring of fluoride contents in the Sfax-Agareb aquifer waters was achieved for one year (October 2013-2014). Results outline contamination induced by the surrounding industrial activities, especially phosphate treatment, but it is most alarming around the southwestern part of phosphogypsum deposit close to the PG leachate collection basins and where fluoride contents may reach up to $29 \mathrm{mg} / \mathrm{L}$. Such contents largely surpass the Tunisian norms for drinking waters and irrigation water maximum fluoride permissible concentrations.

This characterization was further scrutinized through "Visual MODFLOW" modeling of the solute flow and transport in the Sfax-Agareb aquifer. The concept model was based on a single layer in a steady-state flow regime. Two temporal references (October 2013 and October 2014), for which measured data were available, have been used. 


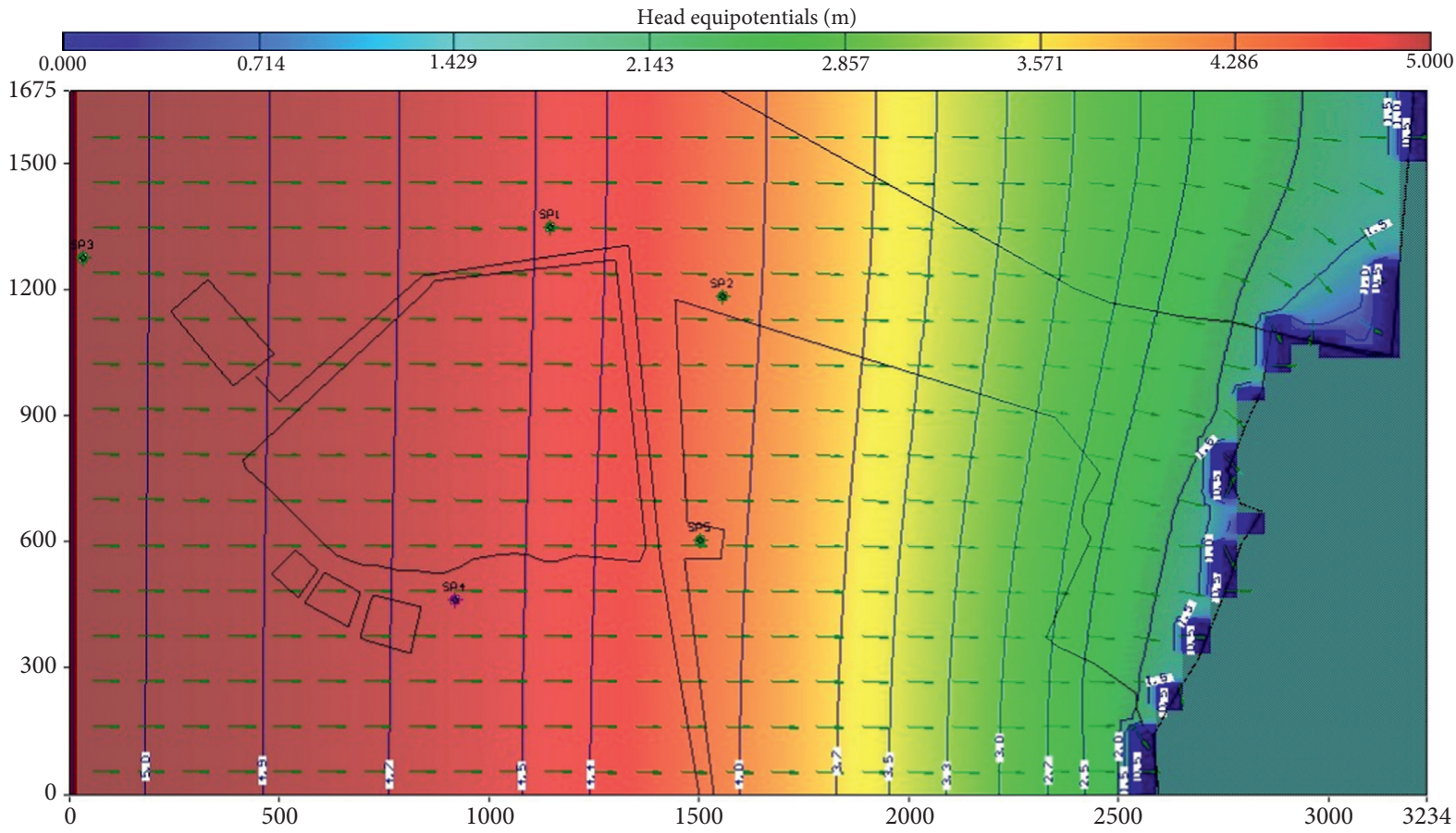

FIgURe 9: Predicted piezometric map of Sfax-Agareb phreatic aquifer at the PG deposit during October 2013.

TABle 2: Calibrated flow model parameters in a steady-state of the Sfax-Agareb groundwaters during October 2013.

\begin{tabular}{lcccc}
\hline Flow parameters & Units & $\begin{array}{c}\text { Before } \\
\text { calibration }\end{array}$ & $\begin{array}{c}\text { After } \\
\text { calibration }\end{array}$ & Description \\
\hline $\begin{array}{l}\text { Hydraulic conductivity of } \\
\text { sand }(K x)\end{array}$ & $\mathrm{m} / \mathrm{s}$ & $8.10^{-6}$ at $1.10^{-3}$ & $2.10^{-4}$ & $\begin{array}{c}\text { Data founded by GCT [42] during the geotechnical } \\
\text { investigations in the study area }\end{array}$ \\
$\begin{array}{l}\text { Hydraulic conductivity of } \\
\text { sand }(K y)\end{array}$ & $\mathrm{m} / \mathrm{s}$ & $2.10^{-4}$ & $2.10^{-4}$ & Data founded by GCT [42] \\
$\begin{array}{l}\text { Hydraulic conductivity of } \\
\text { sand }(K z)\end{array}$ & $\mathrm{m} / \mathrm{s}$ & $2.10^{-5}$ & $2.10^{-5}$ & Data founded by GCT [42] \\
$\begin{array}{l}\text { Refill (effective infiltration) } \\
\text { Effective porosity of sand }\end{array}$ & $\mathrm{mm} / \mathrm{an}$ & 7.6 & 10 & $\begin{array}{c}\text { Values founded by Trabelsi [43] } \\
\text { Total porosity of sand }\end{array}$ \\
\hline
\end{tabular}

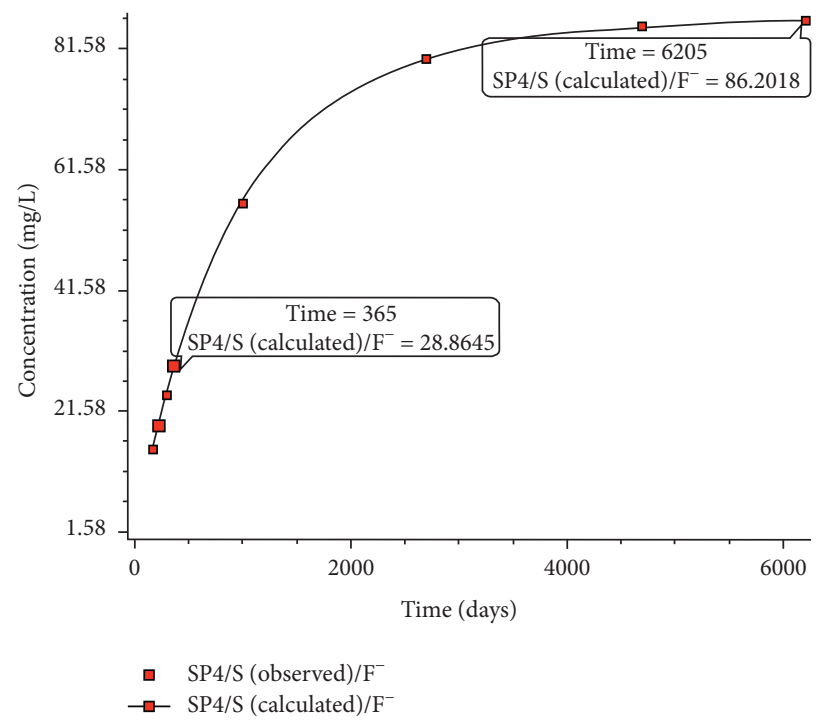

Figure 10: Predicted fluoride concentration between 2014 and 2030 years in Sfax-Agareb phreatic aquifer at the PG deposit. 
TABLE 3: Calibrated transport model parameters of the Sfax-Agareb groundwater during October 2014.

\begin{tabular}{lcccc}
\hline $\begin{array}{l}\text { Migration } \\
\text { parameters }\end{array}$ & Units & $\begin{array}{c}\text { Before } \\
\text { calibration }\end{array}$ & $\begin{array}{c}\text { After } \\
\text { calibration }\end{array}$ & Description \\
\hline $\begin{array}{l}\mathrm{F}^{-} \text {content at the } \\
\text { source zone }\end{array}$ & $\mathrm{mg} / \mathrm{L}$ & 2000 & 250 & $\begin{array}{c}\text { Constant } \mathrm{F}^{-} \text {concentration from the PG leachate collection basins, migrating } \\
\text { within the sandy layer to SP4 piezometer. These concentrations are } \\
\text { calibrated according to the concentration observed at the SP4 piezometer. }\end{array}$ \\
$\begin{array}{l}\mathrm{F}^{-} \text {content at SP4 } \\
\text { Dispersivity of sand }\end{array}$ & $\begin{array}{c}\mathrm{mg} / \mathrm{L} \\
\mathrm{m}\end{array}$ & 29 & 28.86 & $\begin{array}{c}\text { Content observed in October 2014. } \\
\text { Values founded by Spitz and Moreno [45]. }\end{array}$ \\
\hline
\end{tabular}

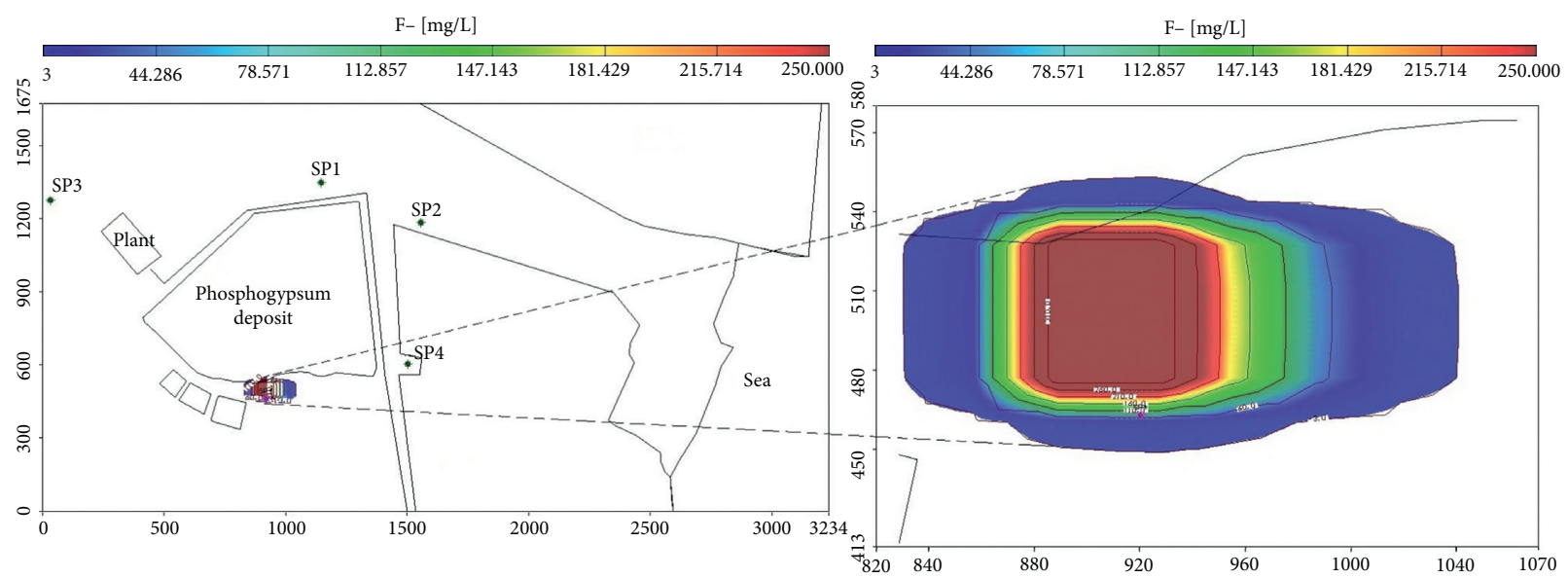

(a)

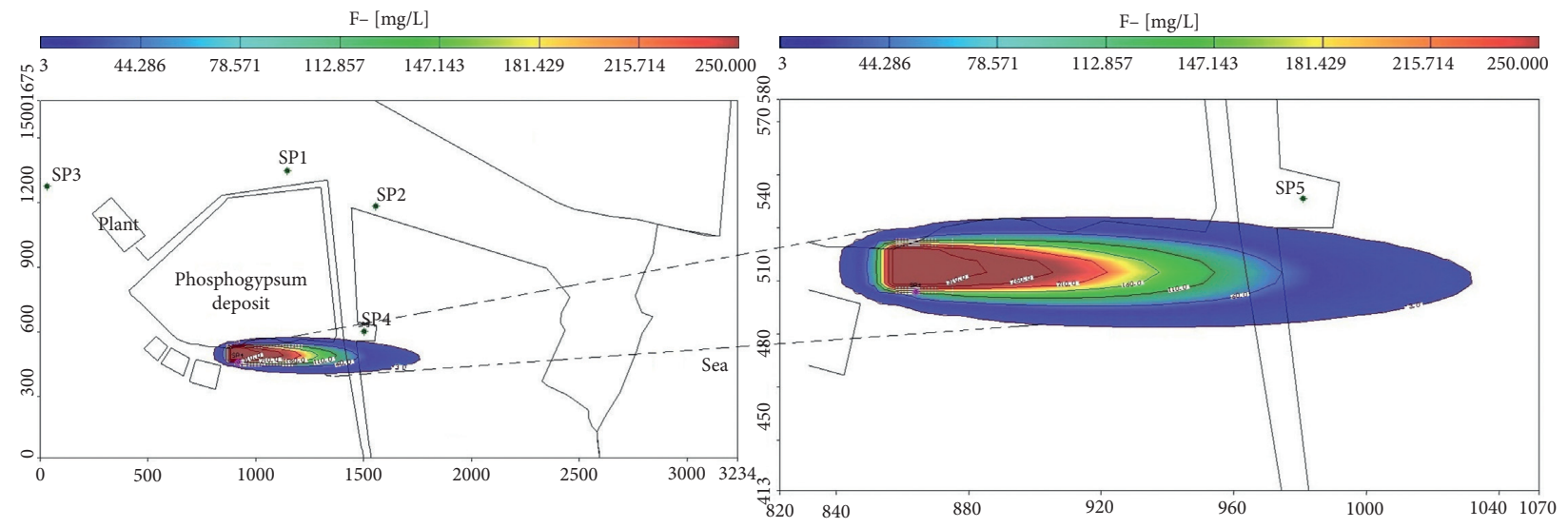

(b)

FIgURE 11: $\mathrm{F}^{-}$pollutant transport in October 2014 (a) and after 16 years (b) in saturated zone of Sfax-Agareb phreatic aquifer at the PG deposit.

Calibration of flow model and transport model was achieved by varying hydraulic conductivity and the dispersivity of sand. The model was calibrated and validated, and predictive simulations were established to assess the extent of the fluoride plume within a simplified framework of a homogeneous and isotropic aquifer. The 16-year predictive simulation (up to 2030), based on a fixed $3 \mathrm{mg} / \mathrm{L}$ concentration front, shows that the spatial expansion of groundwater fluoride contamination spreads towards the sea with an ellipsoid-shaped plume spreading over a distance of $900 \mathrm{~m}$. Fluoride contents are predicted to increase up to $86 \mathrm{mg} / \mathrm{L}$ at the control piezometer in 2030. The quantitative contamination expansion prevision is most distressing and urgent means of remediation have to be implemented. In this context, it is recommended to act upstream and improve the production process to include neutralization of phosphogypsum [34]. It is also recommended to set up means for wastewater recovery and recycling. Hydrogeological isolation by geomembranes and containment of phosphogypsum stocks can be also a good measurement to prevent aquifer pollution [57]. It is also necessary to take preventive measures beforehand and create protected and suitable sites for future phosphogypsum storage.

Already stocked phosphogypsum can be used as a substitute for natural gypsum in the manufacturing of cement [58] and/or the manufacturing of ceramics and plaster 
[59]. This will reduce the huge stock of phosphogypsum left to induce water pollution in the area.

\section{Data Availability}

All data used to support the findings of this study are included within the article and will be, in case the article will be accepted, accessible to readers.

\section{Disclosure}

Amina Mabrouk El Asmi, Mohamadou Ould Baba Sy, and Moncef Gueddari are coauthors.

\section{Conflicts of Interest}

The authors declare that they have no conflicts of interest.

\section{References}

[1] V. V. S. Gurunadha Rao, R. L. Dhar, and k. Subrahmanyam, "Assessment of contaminant migration in groundwater from an industrial development area," Water, Air, and Soil Pollution, vol. 128, no. 3/4, pp. 369-389, 2001.

[2] N. J. Pawar, G. M. Pondhe, and S. F. Patil, "Groundwater pollution due to sugar-mill effluent at Sonai, Maharashtra, India," Environmental Geology, vol. 34, no. 213, pp. 151-158, 1998.

[3] P. E. Rosenfeld and L. G. H. Feng, Risks of Hazardous Wastes, Elsevier, vol. 472, Amsterdam, Netherlands, 2011.

[4] A. D. Flowers and K. W. Linderman, "Hazardous waste disposal: a waste-fuel blending approach," Production and Operations Management, vol. 12, no. 3, pp. 307-319, 2009.

[5] S. Shogo, N. Jun, and N. Kazuyuki, "A survey on characteristics of leachate pond in an offshore municipal solid waste disposal site," Journal of Material Cycles and Waste Management, vol. 18, no. 2, 2014.

[6] W. L. McCulloch, W. L. Goodfellow, and J. A. Black, "Characterization, identification and confirmation of total dissolved solids as effluent toxicants," Environmental Toxicology and Risk Assessment, vol. 2, pp. 213-227, 1993.

[7] F. Allan and E. Elnajjar, "The role of mathematical Modeling in understanding the groundwater pollution," International Journal of Thermal \& Environmental Engineering, vol. 4, no. 2, pp. 171-176, 2012.

[8] C. Zheng and P. P Wang, MT3DMS, a Modular Three-Dimensional Multi-Species Transport Model for Simulation of Advection, Dispersion, and Chemical Reactions of Contaminants in Groundwater Systems, Report to the US Army Corps of Engineers, Washington, DC, USA, 1999.

[9] N. C. Mondal and V.S. Singh, "Mass transport modeling of an industrial belt using visual MODFLOW and MODPATH: a case study," Journal of Geography and Regional Planning, vol. 2, no. 1, pp. 001-019, 2009.

[10] L. De Windt and N. F. Spycher, "Reactive transport modeling: a key performance assessment tool for the geologic disposal of nuclear waste," Elements, vol. 15, no. 2, pp. 99-102, 2019.

[11] M. Marseguerra and E. Zio, "Looking at Monte Carlo simulation for describing nonlinear sorption in groundwater contaminant transport," Mathematics and Computers in Simulation, vol. 55, no. 1-3, pp. 167-176, 2001.
[12] D. A. Benson, "The fractional advection-dispersion equation: development and application," Dissertation of Doctoral Degree, University of Nevada Reno, Reno, NV, USA, 1998.

[13] V. G. Priazhinskaya, D. M. Yaroshevskii, and L. K. LevitGourevich, "Computer modeling in water resources management," Physical and Mathematical Literature Publishing Company, vol. 493, 2002.

[14] V. M. Shnaydman, "The application of the aggregative approach in simulation modeling of water resources systems," Water Resources Management, vol. 6, no. 2, pp. 135-148, 1992.

[15] L. H. Weinstein and A. Davison, Fluorides in the Environment: Effects on Plants and Animals, CABI Publishing, Oxon, UK, 2004.

[16] O. Saether, C. Reimann, B. O. Hilmo, and E. Taushani, "Chemical composition of hard- and softrock groundwaters from central Norway with special consideration of fluoride and Norwegian drinking water limits," Environmental Geology, vol. 26, pp. 147-156, 1995.

[17] J. A. Camargo, "Fluoride toxicity to aquatic organisms: a review," Chemosphere, vol. 50, no. 3, pp. 251-264, 2003.

[18] D. Sujatha, "Fluoride levels in the groundwater of the southeastern part of Ranga Reddy district, Andhra Pradesh, India," Environmental Geology, vol. 44, no. 5, pp. 587-591, 2003.

[19] R. Brunt, L. Vasak, and J. Griffioen, "Fluoride in groundwater: probability of occurrence of excessive concentration on global scale," in Report, International Groundwater Resources Assessment Centre, Westvest, The Netherlands, 2004.

[20] K. W. M. Msonda, W. R. L. Masamba, and E. Fabiano, "A study of fluoride groundwater occurrence in Nathenje, Lilongwe, Malawi," Physics and Chemistry of the Earth, Parts $A / B / C$, vol. 32, no. 15-18, pp. 1178-1184, 2007.

[21] K. M. K. Kut, A. Sarswat, A. Srivastava, C. U. Pittman, and D. Mohan, "A Review of fluoride in african groundwater and local remediation methods," Groundwater for Sustainable Development, vol. 2-3, pp. 190-212, 2016.

[22] S. Melki, "Modélisation de la variation spatio-temporelle de la qualité des eaux des nappes de Sfax-Agareb, de Skhira et de Gabès-Nord au niveau des sites du GCT," Doctoral Thesis, University of Tunis El Manar, Tunis,Tunisia, 2018.

[23] Y. Hamed, L. Dassi, R. Ahmadi, and H. Ben Dhia, "Geochemical and isotopic study of the multilayer aquifer system in the Moulares Redayef basin, southern Tunisia," Hydrological Sciences Journal, vol. 53, no. 5, pp. 1241-1252, 2008.

[24] Y. Hamed, L. Dassi, M. Tarki, R. Ahmadi, K. Mehdi, and H. B. Dhia, "Groundwater origins and mixing pattern in the multilayer aquifer system of the Gafsa-south mining district: a chemical and isotopic approach," Environmental Earth Sciences, vol. 63, no. 6, pp. 1355-1368, 2010.

[25] R. Liteplo, P. Howe, and H. Malcolm, Environmental Health Criteria 227: Fluorides, World Health Organization (WHO), Geneva, Switzerland, 2002.

[26] G. Wang and G. Cheng, "Fluoride distribution in water and the governing factors of environment in arid north-west China," Journal of Arid Environments, vol. 49, no. 3, pp. 601-614, 2001.

[27] M. Baunthiyal and S. Ranghar, "Physiological and biochemical responses of plants under fluoride stress: an overview," Fluoride, vol. 47, no. 4, pp. 287-293, 2014.

[28] F. Khelifi, A. Melki, Y. Hamed, P. Adamo, and A. G. Caporale, "Environmental and human health risk assessment of potentially toxic elements in soil, sediments, and ore-processing wastes from a mining area of southwestern Tunisia," Environmental Geochemistry and Health, pp. 1-15, 2019. 
[29] J. A. Camargo and T. W. La Point, "Fluoride toxicity to aquatic life: a proposal of safe concentrations for five species of palearctic freshwater invertebrates," Archives of Environmental Contamination and Toxicology, vol. 29, no. 2, pp. 159-163, 1995.

[30] P. M. Rutherford, M. J. Dudas, and R. A. Samek, "Environmental impacts of phosphogypsum," Science of The Total Environment, vol. 149, no. 1-2, pp. 1-38, 1994.

[31] GCT, "Rapport complet pour le Lot 1 pour la caractérisation environnementale des sites des usines à Sfax, Skhira et Gabès," Internal Report of the Tunisian Phosphate Company, vol. 84, 2011.

[32] S. Melki and M. Gueddari, "Impact assessment of phosphogypsum on the groundwater of sfax-agareb aquifer, in Southeast of Tunisia," in Proceedings of the ICEWE 2017: 19th International Conference on Energy, Water and Environment, Istanbul, Turkey, February 2019.

[33] S. Melki, A. Mabrouk El Asmi, and M. Gueddari, "Inferred industrial and agricultural activities impact on groundwater quality of Skhira coastal phreatic aquifer in Southeast of Tunisia (Mediterranean region)," Geofluids, vol. 19, 2019.

[34] M. Zairi, "Impact environnementaux du stockage du phosphogypse à Sfax (Tunisie)," Bulletin des laboratoires des Ponts et Chaussées, vol. 4745, pp. 29-40, 1999.

[35] S. Melki and M. Gueddari, "Impact assessment of phosphogypsum leachate on groundwater of sfax-agareb (southeast of Tunisia): using geochemical and isotopic investigation," Journal of Chemistry, vol. 10, 2018.

[36] F. Papanicolaou, S. Antoniou, and I. Pashalidis, "Experimental and theoretical studies on physico-chemical parameters affecting the solubility of phosphogypsum," Journal of Environmental Radioactivity, vol. 100, no. 10, pp. 854-857, 2009.

[37] INM, Climate Data Report for the Period 2005-2015, National Institue of Meteorology of Tunisia, Tunis, Tunisia, 2015.

[38] I. Hentati, M. Zaïri, and H. Ben Dhia, "A statistical and geographical information system analysis for groundwater intrinsic vulnerability: a validated case study from Sfax-Agareb, Tunisia," Water and Environment Journal, vol. 3, no. 25, pp. 400-411, 2011.

[39] M. Ben Akacha, "Etude géologique de la région d'AgarebSfax:Evolution géomorphologique, néotectonique et paléogéologique," vol. 94, University of Sfax, Sfax, Tunisia, 2001, Master thesis.

[40] P. F. Burollet, "Contribution à l'étude stratigraphique de la Tunisie Centrale," Annuaire Géologique des Mines, Tunisie, vol. 18, 1956.

[41] H. Ben Dhia, "Les provinces géothermiques en Tunisie: potentialités géothermiques de la Tunisie méridionale," vol. 183, University of Bordeaux I, Talence, France, 1983, Doctoral thesis.

[42] GCT, "Rapport de reconnaissance géotechnique des sites des usines à Sfax, Skhira et Gabès," Internal Report of the Tunisian Phosphate Company, vol. 67, 2009.

[43] R. Trabelsi, "Contribution à l'étude de la salinisation des nappes phréatiques côtières," Cas du système de Sfax-Mahdia. Doc thesis, ENIS, Sfax, Tunisia, vol. 182, 2008.

[44] J. Rodier, L'analyse de l'eau: Eaux naturelles, eaux résiduaires, eau de mer, Dunod, Paris, France, 8th edition, 2005.

[45] K. Spitz and J. Moreno, A Practical Guide to Groundwater and Solute Transport Modeling, John Wiley \& Sons, Inc., New York, NY, USA, 1996.

[46] A. W. Harbaugh, M. G. McDonald, and D. J. Ackerman, "A method of converting no-flow cells to variable head cells for the U.S. Geological Survey modular finite-difference groundwater flow model: U.S," Geological Survey Open-File Report, vol. 91, 1992.

[47] C. Zheng, J. Weaver, and M. Tonkin, MT3DMS, A Modular Three-Dimensional Multispecies Transport Model-User Guide to the Hydrocarbon Spill Source (HSS) Package, U.S. Environmental Protection Agency, Athens, Georgia, 2009.

[48] C. Zheng, "MT3D: a modular 3-D transport model for simulation of advection, dispersion, and chemical reactions of contaminants in groundwater systems," Report to the Kerr Environmental Research Laboratory, US Environmental Protection Agency, Ada, Ok, USA, 1990.

[49] J. Bear, M. S. Beljin, and R. R. Ross, Fundamentals of GroundWater Modelling Ground Water Issue, Nova Publisher, Hauppauge, NY, USA, EPA/540/S-92/005, 1992.

[50] A. Bahri, "Wastewater reclamation and reuse in Tunisia," in Wastewater Reclamation and Reuse, Water Quality Management Library, T. Asano, Ed., vol. 10, pp. 877-916, Technomic Publishing Co, Inc, Lancaster, PA, USA, 1998.

[51] A. Dassargues, "Modèles mathématiques en hydrogéologie et paramétrisation," Anales de la Société Géologique de Belgique, vol. 113, no. 2, pp. 217-229, 1990.

[52] C. J. Newell, S. K. Farhat, D. T. Adamson, and B. B. Looney, "Contaminant plume classification system based on mass discharge," Ground Water, vol. 49, no. 6, pp. 914-919, 2011.

[53] M. G. McDonald and A. W. Harbaugh, "A modular threedimensional finite-difference ground-water flow model," in U.S.G.S. Techniques of Water-Resources Investigations, U.S. GPO, Washington, DC, USA, Book 6, 1988.

[54] L. F. Konikow, D. J. Goode, and G. Z. Hornberger, “A threedimensional method-of-characteristics solute-transport model (moc3d), water-resources investigations," Technical Report 96-4267, US Geological Survey, Reston, Virginia, 1996.

[55] G. De Filippis, S. Margiotta, C. Branca, and S. Negri, "A modelling approach for assessing the hydrogeological equilibrium of the karst, coastal aquifer of the salento peninsula (southeastern Italy): evaluating the effects of a MAR facility for wastewater reuse," Geofluids, vol. 2019, Article ID 5714535, 19 pages, 2019.

[56] O. Banton and L. M. Bangoy, "Hydrogéologie: multiscience environnementale des eaux souterraines," Presse de l'Université du Québec.vol. 460, 1999.

[57] R. Hakkou, M. Benzaazoua, and B. Bussière, "Valorization of phosphate waste rocks and sludge from the Moroccan phosphate mines: challenges and perspectives," Procedia Engineering, vol. 138, pp. 110-118, 2016.

[58] F. Khelifi, H. Besser, Y. Ayadi et al., "Evaluation of potentially toxic elements'(PTEs) vertical distribution in sediments of Gafsa-Metlaoui mining basin (Southwestern Tunisia) using geochemical and multivariate statistical analysis approaches," Environmental Earth Sciences, vol. 78, no. 2, p. 53, 2019.

[59] H. Baccour, H. Koubaa, and S. Baclouti, "Phosphate sludge from Tunisian phosphate mines: valorisation as ceramics products," in Recent Advances in Environmental Science from the Euro-Mediterranean and Surrounding Regions, A. Kallel, M. Ksibi, H. Ben Dhia, and N. Khélifi, Eds., Springer, Cham, Switzerland, 2018. 